\title{
EFFECT MOIST WOUND HEALING TECHNIQUE TOWARD DIABETES MELLITUS PATIENTS WITH ULKUS DIABETIKUM IN DHOHO ROOM RSUD PROF Dr. SOEKANDAR MOJOSARI
}

\author{
Lutfi Wahyuni \\ STIKES Bina Sehat PPNI Mojokerto
}

\begin{abstract}
Wound healing of ulkus diabetikum depends on wound treatment given; an appropriate wound treatment technique is able to help the healing process quickly and prevent amputation effectively. It needs wound treatment that is able to prevent advanced complication and increase wound healing process such as moist wound healing. This study aimed to aplicated technique with moist wound healing toward diabetes mellitus patients with ulcer diabetic in dhoho room RSUD Prof Dr. Soekandar Mojosari. Deskriptive explorative research design was used in this study. The number of sample were 20 respondents who were the whole ulcer diabetic patients on January - March 2016. The date were collected from the $1^{\text {st }}$ and $7^{\text {th }}$ wound treatment days of embroider medic and used observation sheets. The findings revealed that 20 respondents were on wound healing degree with regeneration wound; it means that the whole respondents cared by moist wound healing within 7 days got regeneration wound or net amelioration. Moist wound healing technique is able to keep moist of wound itself, so that it can facilitate cell and wound movement as well as expedite the granulation process about 50\%. Therefore, after doing wound healing during 7 days, the significant change was on wound granulation development. Besides, it can minimize cell damage while the alteration bandage in order to prevent the new trauma and wound spread.
\end{abstract}

Key words: Moist Wound Healing Technique and Ulcer Diabetic 


\section{PENDAHULUAN}

Penyakit diabetes mengakibatkan kegagalan penyembuhan pada ulkus tersebut, yang disebabkan oleh infeksi sebagai akibat dari tingginya glukosa, sehingga mendorong proliferasi bakteri dan pada penderita diabetes melitus sering dijumpai penurunan sistem imun. Selain itu, tidak sesuainya penanganan luka pada ulkus diabetikum juga dapat mempengaruhi proses penyembuhan luka yang terjadi (Ekaputra, 2013).

Dalam melakukan perawatan luka, masih sering kita lihat didalam praktek keperawatan di rumah sakit, pelaksanaan yang dilakukan di ruangan hanya sebatas mengganti balutan luka, membersihkan luka kemudian selesai, tanpa adanya tindakan komprehensif meliputi pengkajian, pemilihan dressing, implementasi, dokumentasi, dan evaluasi.

Penyembuhan luka pada ulkus diabetik sangat bergantung pada perawatan luka yang diberikan, dimana teknik perawatan luka yang tepat dapat membantu proses penyembuhan luka lebih cepat, dan penanganan luka diabetik secara efektif dapat mencegah terjadinya amputasi (Ismail \& Irawaty, 2009). Oleh sebab itu, beberapa rumah sakit memilih menggunakan teknik moist wound healing dalam melakukan perawatan luka, karena teknik moist wound healing sudah banyak diteliti oleh pakar pakar kesehatan dan terbukti memiliki banyak keuntungan daripada menggunakan teknik perawatan luka dengan prinsip kering, serta dengan menggunakan teknik moist wound healing penyembuhkan luka menjadi 3 sampai 5 kali lebih cepat. Data dari United State menyebutkan $6 \%$ penduduk US menderita diabetes, yang $15 \%$ diantaranya mengalami luka kaki diabetes yang diakibatkan karena adanya neuropati sensorik, obesitas, atau iskemia pada klien dengan perokok berat dan sekitar $14-20 \%$ dari pasien yang mempunyai luka tersebut memerlukan amputasi (Ekaputra, 2013).

Pasien dengan ulkus diabetikum yang dirawat dengan advanced wound dressing memiliki presentase perbaikan luka yang lebih tinggi sekitar $86,67 \%$ dibandingkan dengan pasien yang dirawat dengan conventional wound dressing. Serta pasien yang dirawat denganadvanced wound dressing lama perawatan lebih pendek sekitar 3-7 hari dibandingkan dengan menggunakan conventional dressing membutuhkan lama perawatan sekitar $>7$ hari. Pada penelitian di atas, advanced wound dressing merupakan salah satu cara untuk mempertahankan luka dalam keadaan lembab. Perawatan luka dengan menggunakan prinsip lembab dan tertutup yang dikenal dengan teknik moist wound healing (Septiyanti \& Damanik, 2013). Teknik moist wound healing merupakan teknik penangganan luka dengan cara menjaga keadaan luka agar tetap lembab sehingga dapat menfasilitasi pergerakan sel pada luka, serta dapat mempercepat proses granulasi sebesar $40 \%$ dari pada luka dengan keadaan kering (Koutoukidis \& Lawrence, 2009). Teknik moist wound healing ini menunjukkan bahwa eksudat luka dapat memberikan bahan - bahan yang dibutuhkan dalam proses penyembuhan, seperti enzim, growth factors, dan faktor kemotaktik dimana dapat mengendalikan infeksi, serta dapat menyediakan lingkungan yang terbaik dalam proses penyembuhan (Hendrickson, 2005).

\section{METODE}

Desain penelitian yang digunakan dalam penelitian ini adalah deskriptif yang merupakan suatu metode penelitian yang dilakukan dengan tujuan untuk membuat gambaran tentang suatu keadaan secara objektif melalui studi kasus (Setiadi, 2013). Peneliti akan mengobservasi sampel yang menggunakan perawatan luka dengan teknik moist wound healing, kemudian digambarkan proses penyembuhan lukanya. Studi kasus merupakan rancangan penelitian yang mencakup pengkajian satu unit penelitian secara intensif, misalnya pada satu pasien, keluarga, kelompok atau institusi. Meskipun jumlah dari subyek sedikit, jumlah variabel yang diteliti sangat luas. Oleh karena itu, sangat penting untuk mengetahui semua variabel yang berhubungan dengan penelitian. Desain ini, tergantung dari keadaan kasus, tetapi tetap mempertimbangkan waktu, serta riwayat dan perilaku sebelumnya biasanya dikaji secara rinci (Nursalam, 2013). Peneliti menggunakan desain penelitian tersebut, karena peneliti ingin mengetahui gambaran penyembuhan luka pada ulkus diabetes yang diberikan perawatan luka dengan teknikmoist wound healing

Populasi pada penelitian ini adalah seluruh pasien diabetes melitus dengan ulkus 
diabetes sejak bulan Januari - Maret 2016 yang sudah mendapatkan perawatan selama 7 hari di Rumah RSUD Prof Dr. Soekandar Mojosari sebanyak 20 orang. Teknik sampling yang digunakan dalam penelitian ini adalah non Probability Sampling yang merupakan teknik pengambilan sampel dengan tidak memberikan peluang yang sama dari setiap anggota populasi, yang bertujuan tidak untuk generalisasi, dan berasa pada probabilitas yang tidak sama (Hidayat, 2010).

Sedangkan, jenis pengambilan sampel yang digunakan adalah "Total Sampling" yang merupakan teknik penentuan sampel jika semua anggota populasi digunakan sebagai sampel. Hal ini dilakukan jika jumlah populasi relatif kecil atau kurang dari 30 orang (Setiadi, 2013). Variabel pada penelitian ini adalah pengaruh teknik moist wound healing pada pasien diabetes melitus dengan ulkus diabetikum. Pada penelitian ini, akan menggunakan lembar observasi perbaikan luka dengan menggunakan instrumen pengukuran luka Bates Jansen dengan nama" Bates-Jansen Wound Assessment Tools (BWAT)" yang merupakan pengembangan dari PSST.BatesJansen Wound Assessment Tools dapat digunakan untuk menilai dan memantau penyembuhan pada luka tekan dan luka kronik lainnya. Pada BWAT terdapat 13 item untuk menilai luka meliputi ukuran luka, kedalaman luka, tepi luka, terowongan, jenis jaringan nekrotik, tipe eksudat, jumlah eksudat, warna kulit sekitar luka, edema, indurasi jaringan perifer, granulasi jaringan, epitelisasi. Pada masing-masing item tersebut memiliki deskripsi karakteristik penilaian dalam bentuk skala berupa skor 1 sampai 5 (Sussman \& Bates-Jansen, 2012). Analisa data pada penelitian ini menggunakan persentase, dimana data kualitatif diubah dalam bentuk persentase dengan cara membagi frekuensi (f) dengan jumlah seluruh observasi $(\mathrm{N})$ dan dikalikan 100. Secara matematik hal tersebut dapat ditulis dengan rumus seperti berikut :

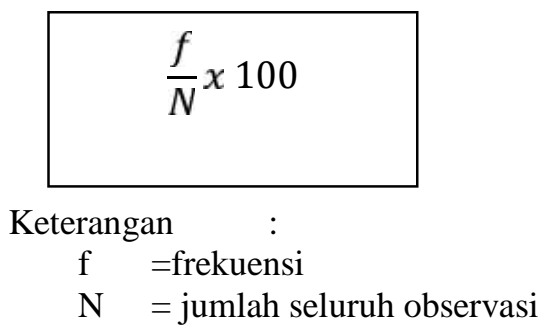

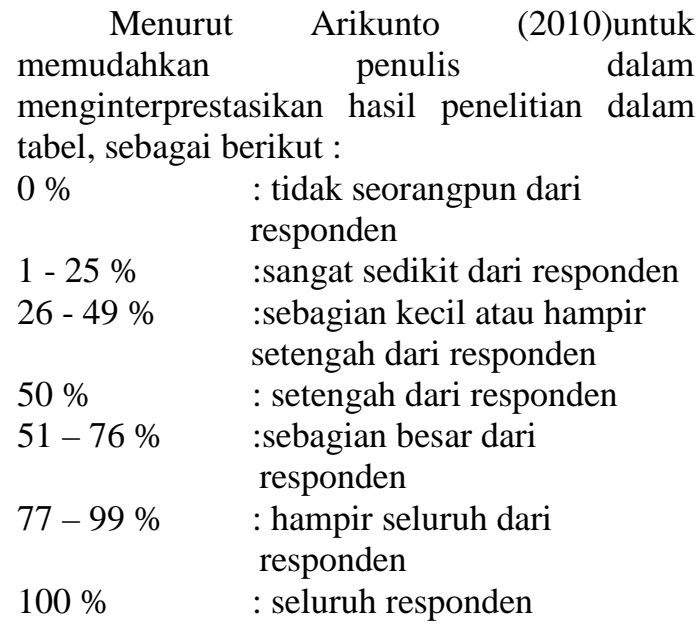

\section{HASIL DAN PEMBAHASAN}

Tabel 1: Distribusi frekuensi responden berdasarkan derajat penyembuhan luka dengan teknik moist wound healing pasien diabetes melitus dengan ulkus diabetikum Bulan Januari - Maret 2016

\begin{tabular}{cccc}
\hline No. & $\begin{array}{c}\text { Penyembuhan } \\
\text { luka }\end{array}$ & $\begin{array}{c}\text { Frekue } \\
\text { nsi }\end{array}$ & $\begin{array}{c}\text { Presentasi } \\
(\boldsymbol{\%})\end{array}$ \\
\hline 1. & Luka sembuh & 0 & $0 \%$ \\
2. & Luka regenerasi & 20 & $100 \%$ \\
3. & Luka degenerasi & 0 & 0 \\
\hline & Total & 20 & $100,0 \%$ \\
\hline
\end{tabular}

Dari data diatas, hasil persentase derajat penyembuhan luka dengan teknik moist wound healingpada pasien diabetes melitus dengan ulkus diabetikum dapat dideskripsikan bahwa seluruh responden sebanyak 20 atau $100 \%$ responden berada pada derajat penyembuhan luka dengan luka regenerasi. Berdasarkan tabel 1 menunjukkan hasil penelitian bahwa seluruh responden ulkus diabetikum dengan menggunakan teknik moist wound healing, menunjukkan luka mengalami regenerasi yaitu $100 \%$.

Luka merupakan rusaknya struktur dan fungsi anatomis normal akibat adanya proses patologis yang berasal dari internal maupun eksternal dan mengenai organ tertentu (Potter \& Perry, 2005). Penyembuhan luka merupakan proses dimana sejumlah jaringan hidup mengalami regenerasi atau pembaruan jaringan. Dimana kemampuan sel dan jaringan akan melakukan regenerasi atau kembali ke struktur normal melalui pertumbuhan sel yang melibatkan proses fisiologis (Kozier \& Erb, 2010). Penyembuhan luka dapat dipengaruhi oleh faktor - faktor antara lain usia, nutrisi, 
vaskularisasi, infeksi, adanya benda asing, hidrasi luka, penyakit penyerta serta penatalaksanaan luka (Arisanty, 2013).

Perawatan luka yang digunakan dalam penelitian ini adalah dengan menggunakan teknik moist wound healing yaitu penyembuhan luka dengan prinsip lembab. Penyembuhan luka lembab adalah dengan menjaga keadaan dasar luka agar tetap atau cukup lembab untuk dapat menfasilitasi pergerakan sel pada dasar luka (Koutoukidis \& Lawrence, 2009). Serta sebuah lingkungan yang lembab pada luka dapat memungkinkan neutrofil dan makrofag untuk bermigrasi dengan lebih baik ( Hendrickson, 2005 ).

Penelitian sebelumnya yang dilakukan Witanto,dkk (2009) menunjukkan bahwa pasien dengan ulkus diabetikum yang dirawat dengan advanced wound dressing memiliki presentase perbaikan luka yang lebih tinggi sekitar $86,67 \%$, serta lama perawatan lebih pendek sekitar 3-7 hari. Penyembuhan luka dengan prinsip lembab juga menunjukkan bahwa eksudat pada luka akan menyediakan sel-sel yang diperlukan oleh kulit untuk proses penyembuhan luka. Serta menyediakan subtrat atau bahan yang kaya akan enzim, growth factors, dan faktor kemotaktik. Dimana faktor kemotaktik berperan untuk mengendalikan infeksi dan menyediakan lingkungan yang terbaik untuk proses penyembuhan ( Hendrickson, 2005 ).

Penatalaksanaan luka merupakan salah satu faktor yang mempengaruhi proses penyembuhan luka. Dimana penatalaksanaan luka yang tepat dapat membantu mempercepat proses penyembuhan luka serta membantu luka untuk beregenerasi. Penatalaksanaan luka selain harus memperhatikan kebersihan luka, memilih cairan dan cara irigasi yang benar, melakukan debridement jaringan nekrotik, juga diperlukan cara memilih balutan yang sesuai dengan keadaan luka. Pemilihan balutan harus bertujuan untuk menjaga luka agar tetap lembab. Karena keadaan luka yang moist atau lembab dapat meningkatkan proses mitosis,meminimalkan rasa sakit dan trauma saat ganti balutan, serta membantu pergerakan sel pada luka, sehingga meningkatkan terjadinya regenerasi sel pada luka.

Hasil penelitian menunjukkan bahwa $100 \%$ responden dengan ulkus diabetikum, lukanya mengalami regenerasi setelah dilakukan perawatan luka dengan teknik moist wound healing selama 7 hari. Dimana saat dilakukan observasi dengan membandingkan pengkajian awal dengan pengkajian hari ke 7, didapatkan data bahwa tidak ada perubahan yang signifikan pada ukuran luka, kedalaman, terowongan atau goa, dan epitelisasi. Namun, pada tipe jaringan nekrotik, jumlah nekrotik, tipe eksudat, jumlah eksudat, dan jaringan granulasi mengalami sedikit perubahan pada seluruh responden, hal ini dapat dilihat dari adanya penurunan satu poin pada item -item tersebut dalam pengkajian.

Selain data diatas, terdapat data yang bisa dikaitkan dengan penyembuhan luka yakni usia. Pada lampiran 9 menunjukkan hampir setengah dari responden dengan usia 59-67 tahun yang mengalami luka regenerasi sebanyak 6 responden (40\%). Penelitian tersebut sama dengan hasil penelitian Nizam (2014), bahwa kejadian ulkus diabetikum banyak terjadi pada rentang usia 56-65 tahun.Usia dapat mempengaruhi penyembuhan luka yang terjadi, pada usia lanjut terjadi penurunan fungsi tubuh sehingga dapat memperlambat waktu penyembuhan luka. Jumlah dan ukuran fibroblas menurun, begitu juga kemampuan proliferasi sehingga terjadi penurunan respons terhadap growth factor dan hormon - hormon yang dihasilkan selama penyembuhan luka. Selain itu, jumlah dan ukuran sel mast juga menurun, serta kondisi kulit yang cenderung kering, keriput, dan tipis sangat mudah mengalami luka karena gesekan dan tekanan, sehingga hal tersebut menyebabkan luka pada usia lanjut akan lebih lama sembuhnya(Arisanty, 2013).

Hasil penelitian yang ada menunjukkan responden ulkus diabetikum dengan usia 59-67 tahun lebih banyak yang mengalami luka regenerasi dari pada responden dengan usia 3249 tahun. Hal tersebut dapat disebabkan karena pada responden dengan usia 59-67 tahun sebagian besar memiliki kadar gula yang terkontrol dan sebagian besar tidak memiliki penyakit penyerta lain selain diabetes melitus. Selain itu, dalam penelitian ini pada faktor usia tidak diseragamkan mengakibatkan pengelompokkan usia sesuai dengan respoden yang ada.

Selain usia, pada pasien diabetes melitus dengan ulkus diabetikum, kadar glukosa darah juga dapat mempengaruhi penyembuhan luka. Berdasarkan lampiran 9menunjukkan bahwa hampir setengah responden dengan kadar gula darah 121-137 mg/dl mengalami luka regenerasi sebanyak 7 responden $(46,7 \%)$. Hal ini sesuai dengan penelitian Handayani (2010) bahwa gula darah mempengaruhi dan berpola positif terhadap perkembangan proses 
penyembuhan ulkus, serta kadar gula yang mendekati normal dapat menurunkan skor penyembuhan ulkus semakin besar. Tidak terkontrolnya kadar gula darah akan memberikan efek yang tidak baik. Jumlah makrofag selama fase inflamasi akan berkurang dan dapat menghambat penyembuhan luka yang terjadi, kadar gula darah yang tinggi juga dapat mengganggu sirkulasi dan nutrisi tidak dapat masuk ke dalam sel, sehingga luka tidak akan mengikuti fase - fase penyembuhan fisiologi (Ekaputra, 2013).

Pada penelitian ini, sebagian besar responden memiliki kadar gula darah yang cukup terkontrol dan tidak ada responden yang memiliki kadar gula > 200mg/dL, sehingga proses penyembuhan luka dapat terjadi dan luka mengalami regenerasi. Selain itu, pada responden yang memiliki kadar gula darah 121- $137 \mathrm{mg} / \mathrm{dL}$ mengalami penurunan skorpaling banyak 14 poin, begitu juga pada responden dengan kadar gula darah 138-154 $\mathrm{mg} / \mathrm{dL}$ mengalami penurunan skor paling banyak 14 poin. Berbeda dengan responden yang memiliki kadar gula darah 155-171 $\mathrm{mg} / \mathrm{dL}$, mengalami penurunan skor paling banyak sekitar 7 poin.

Penyakit penyerta juga dapat menjadi salah satu faktor yang memperlambat penyembuhan luka. Berdasarkan lampiran 9 menunjukkan sebagian besar responden diabetes melitus dengan ulkus diabetikum memiliki penyakit penyerta lainnya yaitu anemia dengan luka regenerasi sebanyak 4 responden $(57,1 \%)$. Hal ini berbeda dengan hasil penelitian Arifin (2007) bahwa penderita diabetes melitus lebih banyak ditemukan penyakit penyerta hipertensi. Penyakit penyerta sering mempengaruhi penyembuhan luka, karena dapat memperberat kerja sel dalam memperbaiki luka (Arisanty, 2013). Anemia merupakan berkurangnya suplai sirkulasi sel darah merah sehingga mempengaruhi jumlah darah pada luka. Sel darah merah merupakan kaya akan oksigen, maka jika terjadi anemia dapat mengurangi suplai oksigen yang menuju luka. Begitu juga dengan hipertensi dapat memperlambat penyembuhan luka karena adanya gangguan aliran darah yang terjadi. Hipertensi dapat mengurangi tingkat perfusi jaringan yang terjadi, sehingga suplai oksigen yang masuk kedalam jaringan menjadi berkurang. Padahal oksigen sangat berperan penting di dalam pembentukan kolagen, kapiler - kapiler baru, dan perbaikan epitel, serta pengendalian infeksi (Morison, 2003). Selain itu, penyakit penyerta lainnya seperti gagal ginjal dapat menyebabkan terjadinya anemia, karena berkurangnya pembentukan sel darah merah akibat defisiensi pembentukan eritropoetin dan masa hidup sel darah merah juga lebih singkat. Serta, dapat terjadi uremia yakni keadaan kronik yang berkaitan dengan meningkatnya urea di dalam darah sehingga dapat menghambat granulasi luka. Hasil penelitian yang ada sesuai dengan teori, bahwa penyakit penyerta seperti anemia, hipertensi, dan gagal ginjal dapat mempengaruhi penyembuhan luka. Hal tersebut dapat dilihat dari perbandingan skor pengkajian awal dan skor pengkajian hari ke 7, menunjukkan pada responden ulkus diabetikum dengan penyakit penyerta mengalami penurunan skor yang lebih sedikit dibandingkan dengan responden ulkus diabetikum tanpa penyakit penyerta, meskipun memiliki kadar gula darah yang terkontrol.

\section{SIMPULAN}

Hasil penelitian tentang pengaruh teknik moist wound healing pada pasien diabetes melitus dengan ulkus diabetikum yang dilaksanakan di di Ruang Dhoho RSUD Prof Dr. Soekandar Mojosari menunjukkan bahwa seluruh responden (100\%) mengalami luka regenerasi setelah dilakukan rawat luka selama 7 hari.

\section{DAFTAR PUSTAKA}

Arifin, I., Prasetyaningrum, E., \& Andayani, T. M. (2007). Evaluasi Kerasionalan Pengobatan Diabetes Melitus Tipe 2 Pada Pasien Rawat Inap Di Rumah Sakit Bhakti Wira Tamtama Semarang Tahun 2006. Jurnal Ilmu Farmasi dan Farmasi Klinik Vol.4 No.1 Juni 2007.

Arikunto, S. (2010). Prosedur Penelitian Suatu Pendekatan Praktik. Jakarta: Rineka Cipta.

Arisanty, I. P. (2013). Konsep Dasar Menejemen Perawatan Luka. Jakarta: EGC.

Billota, K. A. (2009). Kapita Selekta Penyakit Dengan Implikasi Keperawatan Edisi 2. Jakarta: ECG. 
Ekaputra, E. (2013). Evolusi manajemen Luka Menguak 5 Keajaiban Moist Dressing. Jakarta: TIM.

Graham Brown, R., \& Burns, T. (2008). Lecture Notes On Dermatologi Edisi Kedelapan. Jakarta: Erlangga.

Hadi, S. (2004). Metodologi Research Untuk Penulisan Laporan, Skripsi, Thesis \& Disertasi Jilid 3. Yogyakarta: ANDI.

Handayani, T. N. (2010). Pengaruh Pengelolaan Depresi Dengan Latihan Pernafasan Yoga (PRANAYAMA) Terhadap Perkembangan Proses Penyembuhan Ulkus Diabetikum Di Rumah Sakit Pemerintah Aceh.

Hendrickson, D. A. (2005). Wound Care for The Equine Practioner. South Hny: Teton New Media.

Hidayat, A. A. (2010). Metode penelitian Kebidanan \& Teknik Analisa Data. Jakarta: Salemba Medika.

Ismail, D. D., \& Irawaty, D. (2009). Penggunaan Balutan Modern Memperbaiki Penyembuhan Luka Diabetik. Jurnal Kedokteran Brawijaya Vol. XXV, No.1 .

Koutoukidis, G., \& Lawrence, K. (2009). Tabber's Nursing Care : Theory and Practice 5th Ed. Catswood: Alsevier Australia.

Kozier, B., \& Erb, G. (2010). Buku Ajar Fundamental Keperawatan Konsep, Proses, Praktek Edisi 7 Volume 2. Jakarta: ECG.

LPPM. (2014). Buku Panduan Penyusunan KTI dan SKRIPSI. Mojokerto: LPPM STIKES BINA SEHAT MOJOKERTO.

Maryunani, A. (2013). Perawatan Luka Modern ( Modern Wound Care) Terkini dan Terlengkap. Jakarta: In Media.

Misnadiarly. (2006). Diabetes Melitus, Gangren Ulcer, Infeksi, mengenal Gejala, Menanggulangi, dan Mencegah Komplikasi. Jakarta: Pustaka Populer Obor.

Morison, M. J. (2003). Manajemen Luka. Jakarta: EGC.

Mubarok, W. I. (2011). Promosi Kesehatan Untuk Kebidanan. Jakarta: Salemba Medika.

Nizam, W. K., Hasneli, Y., \& Arneliwati. (2014). Faktor-Faktor Yang Mempengaruhi Citra Tubuh Pasien
Diabetes Melitus Yang Mengalami Ulkus Diabetikum. JOM PSIK VOL.1 NO.2 OKTOBER 2014 .

Notoatmodjo, S. (2012). Metodologi Penelitian Kesehatan. Jakarta: Rineka Cipta.

Nursalam. (2013). Metodologi Penelitian Ilmu Keperawatan Pendekatan Praktis Edisi 3.Jakarta: Salemba Medika.

Potter, P. A., \& Perry, A. G. (2005). Buku Ajar Fundamental Keperawatan Konsep, Proses, dan Praktik Edisi 4 volume 2. Jakarta: ECG.

RISKESDAS. (2013). Riset Kesehatan Dasar. Jakarta: Badan Penelitian dan Pengembangan Kesehatan Departemen Kesehatan Republik Indonesia.

Riyadi, S., \& Sukarmin. (2008). Asuhan Keperawatan Pada Pasien Dengan Gangguan Ensokrin \& Endokrin Pada Pankreas. Yogyakarta: Graha Ilmu.

Septiyanti, M., \& Damanik, S. R. (2013). Hubungan Tingkat Pengetahuan Dengan Sikap Perawat Tentang Perawatan Luka Diabetes Menggunakan Teknik Moist Wound Healing.

Setiadi. (2013). Konsep dan Praktik Penulisan Riset Keperawatan Edisi 2. Yogyakarta: Graha Ilmu.

Sri Kusuma Dewi, M. F. (2009). Informatika Kesehatan. Yogyakarta: RPI.

Sugiyono. (2013). Statistika Untuk Penelitian. Bandung: Alfabeta.

Supranto, J. (2000). Statistik Teori dan Aplikasi Jilid 1 Edisi Keenam. Jakarta: Erlangga.

Suriadi. (2014). Ilustrasi Berwarna Perawatan Luka Untuk Perawat, Bidan, dan Paramedis. Tangerang: Binarupa Aksara Publisher.

Suriadi. (2004). Perawatan Luka. Jakarta: CV. Sagung Seto.

Sussman, C., \& Bates-Jansen, B. (2012). Wound Care A Collaborative Pratice Manual for Health Professionals Fourth Edition. Philadephia: Lippincat Williams \& Wolters Kluwer.

Waluyo, S. (2009). 100 Questions \& Answers DIABETES. Jakarta: PT. Elex Media Komputindo.

WHO. (2012). Dipetik November 10, 2014, dari World Health Organization: http://www.who.int 
Witanto, D., Gejali, Y. H., Sandy, Sakti, L. H., \& Pangayoman, R. (2009). Gambaran Umum Perawatan Ulcus Diabeticum Pada Pasien Rawat Inap Di Rumah Sakit Immanuel Bandung Periode Juli 2007-Agustus 2008. JKM Vol.9 No.1 Juli 2009 .

Yuwono, H. S. (2010). Ilmu Bedah Vaskuler Sains dan Pengalaman Praktis. Bandung: PT. Refika Aditama. 